\title{
Adsorption gas Heat Pump fuelled with hydrogen enriched natural gas blends: the analytical simulation model development and validation
}

\author{
Matteo Sforzini ${ }^{1}{ }^{*}$, Gianluigi Lo Basso ${ }^{1}$, Romano Paiolo ${ }^{1}$, Livio De Santoli ${ }^{1}$ and Fabrizio \\ $\mathrm{Cumo}^{2}$ \\ ${ }^{1}$ Department of Astronautics, Electrical and Energy Engineering (DIAEE), Sapienza University of \\ Rome, Via Eudossiana 18, Rome 00184, Italy \\ ${ }^{2}$ Department of Planning, Design, and Technology of Architecture (DPDTA), Sapienza University of \\ Rome, Via Flaminia 72, Rome 00196, Italy
}

\begin{abstract}
This study deals with the implementation of an analytical model to simulate the energy performance associated to a commercial Gas adsorption Heat Pump, when $\mathrm{H}_{2} \mathrm{NG}$ (Hydrogen Enriched Natural Gas) blends are used as fuel. In detail, a water source heat pump manufactured by Robur (GAHP-WS) has been used as a reference device for building the simulation model within the MATLAB-Simulink environment. Thereafter, the simulation results have been validated by the experimental campaign, testing on field and in actual operating conditions the heat pump. Specifically, the model has been developed by implementing the WaterAmmonia mass and energy balances for each component. It is able to evaluate fuel consumption, efficiency in terms of GUE, required thermal power from the cold heat sink as well as the water outlet temperature at the evaporator, once the heating load is used as the main input. The experimental campaign for the model calibration and validation has been carried out over the winter season. Additionally, the heat pump performance has been detected when it operates to supply hot water at $60{ }^{\circ} \mathrm{C}$ and $55^{\circ} \mathrm{C}$, and it is fuelled with growing hydrogen fractions, starting from $0 \%$ vol., $5 \%$ vol. up to $10 \%$ vol. In the end, the standard errors as well as the relative ones affecting the main output parameters have computed for the validation process. From the outcomes it emerges that the average relative standard error related to all load conditions is lower than $2.5 \%$ for natural gas operation. On the contrary, it ranges between $2.5 \%$ and $4 \%$ when $\mathrm{H}_{2} \mathrm{NG}$ at $5 \%$ and $10 \%$ by volume have been burnt.
\end{abstract}

\section{Introduction}

It is well-known how, in the short-medium term, Power-to-Gas (P2G) technologies application can effectively contribute to the energy systems' decarbonisation pathway. Specifically, the renewable hydrogen production hailing from the electricity excess occurrence, and its cofiring with other fossil fuels, such as natural gas, offer new

\footnotetext{
*Corresponding author: matteo.sforzini@uniroma1.it
} 
opportunities. Indeed, the hydrogen enriched natural gas blends $\left(\mathrm{H}_{2} \mathrm{NG}\right)$ wide deployment allows, quite easily, to get the natural gas network greening targets by 2050 . Adopting such a strategy, it is possible to exploit the existing infrastructures for storing hydrogen, reducing also the capital expenditure related to dedicated systems for its management. Therefore, a future energy context, in which hydrogen can be used by the most common end-users, is not so far. It is important to point out that $\mathrm{P} 2 \mathrm{G}$ is one of the suitable options for figuring out all those issues related to the renewable capacity firming, as it can be found in literature $[1,2]$. Yet, the cost-effective hydrogen production has to be necessarily integrated in new energy scenarios. That approach imposes to rethink the previous energy model, allowing to analyse and implement the Smart mutual interactions between different sectors, as well as at different scale [3-5]. To do so, in recent years, the Smart Energy Systems concept was introduced by several academic authors [6-9]. Depending on the boundary conditions associated to each energy system, the hydrogen use can play marginal or key role in the next future. For instance, in NG-based countries the hydrogen injection within the pipelines represents a valid complementary strategy, together with DR (Demand Response) activities, to increase the RES (Renewable Energy Sources) fraction within the National Grids [10,11]. Having said this, the $\mathrm{H}_{2} \mathrm{NG}$ blends application entails to cope with several technical features associated to the NG distribution networks [12-14] and safety issues for both industrial and household appliances [15]. In the last decade, several research projects were carried out to explore which were the potential advantages and drawbacks for the most common commercial devices, hailing from the hydrogen blending [16-21]. Notwithstanding, from literature review it emerges that the research efforts were mainly focused on reciprocating internal combustion engines, on MGTs (Micro Gas Turbines) and on boilers behaviour, when they are fuelled with $\mathrm{H}_{2} \mathrm{NG}$ [22-25]. To the best of the authors knowledge, research projects dealing with Gas Adsorption Heat Pumps (GAHP), powered by hydrogen blends are missing. Therefore, the topic addressed in this paper can positively contribute to the knowledge in this field, representing in fact a novelty. GAHPs are generally characterised by lower conversion efficiency values compared to those related to electric Heat Pumps [26,27]. That technology was originally developed for providing chilled water, but its coefficient of performance barely is beyond 0.7 , unless the multi-stage layout is adopted. Nevertheless, by the refrigerant cycle inversion the modern GAHPs are able to provide heat characterised by a COP higher than unity, close to 1.6 [28,29]. For that reason, they are typically suitable for buildings refurbishment interventions, where high supply water temperature is required [30]. Several research projects investigated on the possibility to integrate such machines with other renewable energy sources or thermal cascade [31,32] to improve the system overall efficiency and to reduce the primary fossil energy consumption.

In the end, the aim of this paper is to investigate on how the hydrogen enrichment could affect the operation of a commercial GAHP, proposing an analytical model based on experimental data. The main findings have been presented here.

\section{Test rig description and methodology}

This study deals with the analytical model implementation of a commercial water source adsorption heat pump in order to simulate its energy performance. Specifically, the most relevant operating parameters have been computed when the heat pump is fuelled with $\mathrm{H}_{2} \mathrm{NG}$ blends. The reference device was manufactured by Robur Company (i.e. the GAHP-WS model), characterised by a rated thermal power output of $35.8 \mathrm{~kW}$ when the GAHP operates under typical conditions for its certification (i.e. supply water temperature equal to $65{ }^{\circ} \mathrm{C}$, inlet water temperature at the evaporator equal to $10^{\circ} \mathrm{C}$ ). In such conditions the rated GUE is 1.42 . The refrigerant/absorbent pair consists of a water/ammonia solution. Fig 1. depicts the GAHP functional scheme for heating purpose. 


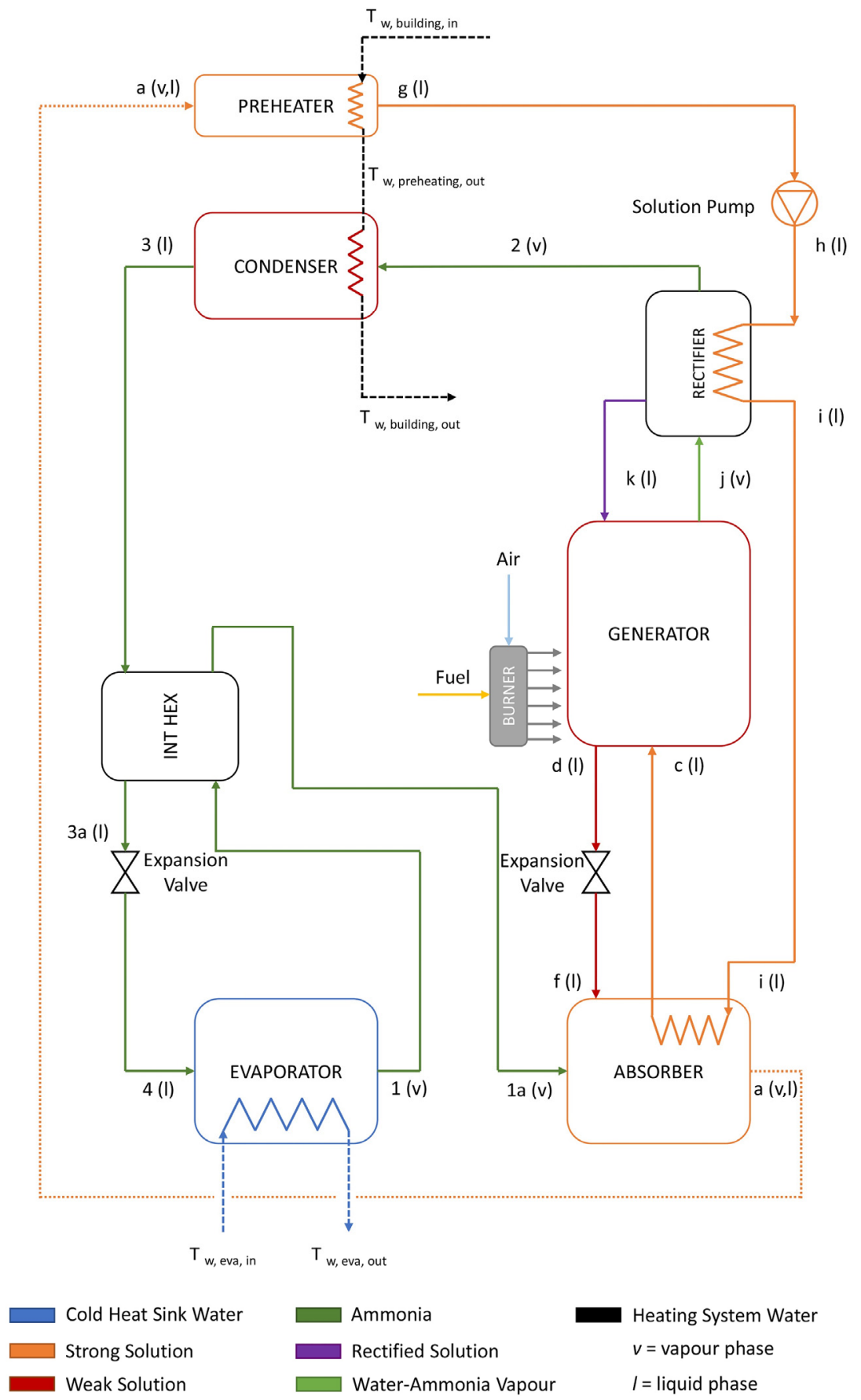

Fig. 1. Robur GAHP-WS operating scheme

Referring to Figure 1, at state $1 a$ the ammonia is in the vapor phase, it flows through the absorber, where it is diluted and then it is mixed with the weak solution coming from the generator (flow $f$ ). The weak solution is a mixture of water and ammonia where generally the water concentration is higher than the ammonia one. Within the absorber an exothermic 
chemical reaction occurs, so that a heat release has to be removed. To do so, a heat exchanger is installed in order to preheat the strong solution (i.e. from state $i$ to the state $c$ ). By that recovery architecture the fuel consumption can be lowered increasing the heat pump efficiency. Downstream the absorber it is possible to notice a two-phase solution, which is characterised by a high temperature and therefore it is used for heat recovery. That recovery occurs within the pre-heater, where the two-phase solution is cooled down up to the saturation conditions, condensing also the remaining part of vapour. The solution pump increases the strong solution operating pressure (flow $g$ ), starting from the evaporator operating conditions. Thus, the liquid solution (from state $h$ ) passes through the rectifier where it is heated up (state $i$ ) and finally it moves to the absorber heat exchanger. In such a way, it is possible to condense out the residual humidity (state $k$ ) hailing from the generator at the state $j$. In so doing, pure ammonia leaves the rectifier towards the condenser (i.e state 2) so that the heat release to the end user can be completed. The gas burner provides thermal energy for separating ammonia from water as much as possible. However, at state $j$ ammonia is not yet completely pure. From the generator bottom-side, the weak solution at high pressure is delivered to an expansion valve in order to restore the right solution concentration within the absorber, to close the thermodynamic cycle. In regards of condenser, it worth of noticing that the ammonia vapour at state 2 is slightly superheated. Therefore, within the condenser sensible and latent heat has to be recovered to get the supply water temperature set point. Finally, an additional regenerative heat exchanger is used for cooling down ammonia downstream the condenser and to heat up the ammonia vapour leaving the evaporator. Obviously, in the evaporator a phase change occurs, extracting low grade heat from the water source which is connected to a renewable thermal power plant (i.e. PV/T).

The experimental campaign has been carried out by testing the heat pump under actual operating conditions in heating mode. Those tests are referred to a time span equal to 5 months over the winter season. The operating parameters have been collected by a virtual PLC and the sample time has been fixed equal to 15 minutes. That system is equipped with 2 electronic 2-ways valves able to keep under control the flow rate values and to calculate also thermal power as well as the energy. Those devices were manufactured by Belimo and they have been installed in the end-user hydraulic loop as well as in the renewable one. The thermal load refers to a low efficiency building which is used as university laboratory. The HVAC system provides the inner space cooling and heating by means of an exchange coil operating with supply water temperature ranging in $50{ }^{\circ} \mathrm{C}$ and $60{ }^{\circ} \mathrm{C}$. Therefore, the experimental campaign has been carried out having fixed two different set points, i.e. supply water temperatures equal to $60{ }^{\circ} \mathrm{C}$ and $55^{\circ} \mathrm{C}$. Moreover, $\mathrm{H}_{2} \mathrm{NG}$ blends have been used for powering the GAHP in both operating conditions, with varying the hydrogen fraction from $0 \%$ vol. up to $10 \%$ vol. The required hydrogen is produced on site by an alkaline electrolyser. The electricity dedicated to the hydrogen production comes from the PV/T system located on the laboratory roof and from the national grid.

The electrolyser capability is $1.15 \mathrm{Nm}^{3} / \mathrm{h}$ which requires a specific consumption equal to 5 $\mathrm{kWh} / \mathrm{Nm}^{3}$.

Table 1. Measurement equipment characteristics

\begin{tabular}{|l|c|l|}
\hline \multicolumn{1}{|c|}{ Components } & Range measurement & \multicolumn{1}{c|}{ Accuracy } \\
\hline $\begin{array}{l}\text { Bronkhorst } \mathrm{H}_{2} \\
\text { mass flow rate metre }\end{array}$ & $0-1.5 \mathrm{Nm}^{3} / \mathrm{h}$ & $\pm 0.5 \% \mathrm{RD}$ plus $\pm 0.1 \% \mathrm{FS}$ \\
\hline $\begin{array}{l}\text { Bronkhorst NG } \\
\text { mass flow rate metre }\end{array}$ & $0-20 \mathrm{Nm}^{3} / \mathrm{h}$ & $\pm 0.5 \% \mathrm{RD}$ plus $\pm 0.1 \% \mathrm{FS}$ \\
\hline PT100 High temperature & $-60+600{ }^{\circ} \mathrm{C}$ & $\pm 0.3{ }^{\circ} \mathrm{C} @ 0,0{ }^{\circ} \mathrm{C}$ \\
\hline PT100 Low temperature & $-30+200{ }^{\circ} \mathrm{C}$ & $\pm 0.15{ }^{\circ} \mathrm{C} @ 0{ }^{\circ} \mathrm{C}$ \\
\hline $\mathrm{O}_{2}$ probe & $0-25 \%$ vol. & $\pm 0.1 \mathrm{vol} \%$ \\
\hline
\end{tabular}


The hydrogen produced is instantly used, avoiding storage devices, and it can be mixed with natural gas. The desired mixture composition is managed by the electrolyser PLC by means of 2 mass flow meters. Finally, the $\mathrm{O}_{2}$ concentration within the exhaust gas has been measured in order to calculate the relative equivalence ratio $\lambda$ and for validating the simulation model.

\subsection{MATLAB-SIMULINK model}

The simulation model has been developed within the MATLAB-SIMULINK environment by implementing the mass and energy balance equations of all components, i.e. evaporator, absorber, generator, rectifier, condenser, preheater, internal heat exchanger, expansion valve and solution pump. The model has 6 main inputs: thermal power to be supplied to the enduser, water mass flow rate and inlet water temperature to the evaporator (cold sink), water temperature and temperature drop required by the end-user (hot sink) and the relative equivalence ratio. Thus, it is able to evaluate fuel consumption, GUE, the thermal power required by the evaporator and the evaporator outlet water temperature. The GUE is defined as the supplied power to the end-user $\left(\mathrm{P}_{\text {load }}\right)$ divided by the consumed chemical power from fuel by the burner $\left(\mathrm{P}_{\text {fuel }}\right)$, as reported in Equation 1 .

$$
\mathrm{GUE}=\frac{\mathrm{P}_{\text {load }}}{\mathrm{P}_{\text {fuel }}}
$$

In order to properly evaluate the unknown thermodynamic parameters, technical assumptions have been made referring to each component. Those value have been outlined in a systemic overview in Table 2 .

\subsubsection{Evaporator}

The subtracted thermal power from the cold heat sink $\left(\mathrm{P}_{\text {cold source }}\right)$ can be computed as follows:

$$
\mathrm{P}_{\text {th,cold source }}=\dot{\mathrm{m}}_{\mathrm{NH} 3} * \mathrm{l}_{\mathrm{h}, \mathrm{NH} 3}
$$

where, the ammonia flow rate $\left(\dot{\mathrm{m}}_{\mathrm{NH} 3}\right)$ is calculated from the condenser heat balance, while the ammonia latent heat $\left(\mathrm{l}_{\mathrm{hNH} 3}\right)$ is a function of the evaporator operating pressure $\left(\mathrm{p}_{\mathrm{eva}}\right)$.

Such a pressure can be calculated by the Antoine's equation, which is dependent on the ammonia saturation temperature within the evaporator $\left(T_{1}\right)$, according to the Equation 3 . Notwithstanding, the saturation temperature is unknown, and it can be assessed by the socalled E-NTU method for the heat exchanger, as reported in Equation 4.

$$
\begin{gathered}
\ln \mathrm{p}_{\text {eva }}=10.3279-\frac{2132.5}{\mathrm{~T}_{1}-32.98} \\
\mathrm{~T}_{1}=\frac{\mathrm{T}_{\mathrm{w}, \text { eva,out }}-\mathrm{T}_{\mathrm{w}, \text { eva,in }} * \mathrm{e}^{-\mathrm{NTU}} \text { eva }}{\left(1-\mathrm{e}^{-\mathrm{NTU}}\right)} \\
\mathrm{NTU}_{\mathrm{eva}}=\frac{\mathrm{UA}_{\mathrm{eva}}}{\mathrm{m}_{\mathrm{w}, \mathrm{eva}} * \mathrm{Cp}_{\mathrm{w}}}
\end{gathered}
$$

Once $p_{\text {eva }}$ e $T_{1}$ are determined, the specific enthalpy value at the state $1\left(h_{1}\right)$ can be deduced. 
Table 2. Technical assumptions for calculations

\begin{tabular}{|c|c|c|c|c|c|c|}
\hline Components & \multicolumn{6}{|c|}{ Parameters } \\
\hline \multirow{2}{*}{ Evaporator } & $\dot{\mathrm{m}}_{\mathrm{w}, \mathrm{eva}}[\mathrm{kg} / \mathrm{s}]$ & $\mathrm{T}_{\mathrm{w}, \text { eva,in }}\left[{ }^{\circ} \mathrm{C}\right]$ & $\begin{array}{c}\text { UAeva } \\
{[\mathrm{kW} / \mathrm{K}]}\end{array}$ & & & \\
\hline & 0.50 & $\begin{array}{c}\text { from } \\
\text { measurement }\end{array}$ & 2.25 & & & \\
\hline \multirow[b]{2}{*}{ Absorber } & $\mathrm{T}_{\text {sat }}\left[{ }^{\circ} \mathrm{C}\right]$ & $\Delta \mathrm{T}_{\text {c-f }}\left[{ }^{\circ} \mathrm{C}\right]$ & & & & \\
\hline & $\begin{array}{c}\mathrm{T}_{\mathrm{w}, \text { out }}+5 \\
{[33]}\end{array}$ & $x_{2}$ & & & & \\
\hline \multirow{2}{*}{ Generator } & $\mathrm{T}_{\text {gen }}\left[{ }^{\circ} \mathrm{C}\right]$ & $\begin{array}{c}\Delta \mathrm{T}_{\text {gen,weak }} \\
{\left[{ }^{\circ} \mathrm{C}\right]} \\
\end{array}$ & $\Delta \mathrm{T}_{\text {gen,vap }}\left[{ }^{\circ} \mathrm{C}\right]$ & Eexchange & $\begin{array}{c}\eta_{\text {burner }} \\
{[\%]} \\
\end{array}$ & $\lambda$ \\
\hline & 178 & $15[34]$ & 15 & 0.54 & 94 & $\begin{array}{c}\text { from } \\
\text { measurement }\end{array}$ \\
\hline \multirow{2}{*}{ Rectifier } & $\mathrm{T}_{\text {rect }}\left[{ }^{\circ} \mathrm{C}\right]$ & $\begin{array}{c}\Delta \mathrm{T}_{\text {rect,vap }} \\
{\left[{ }^{\circ} \mathrm{C}\right]}\end{array}$ & $\mathrm{y}_{\mathrm{j}}$ & & & \\
\hline & $76[34]$ & 20 [34] & $0.96[33]$ & & & \\
\hline \multirow{2}{*}{ Condenser } & $\Delta \mathrm{T}_{\mathrm{w}, \text { load }}\left[{ }^{\circ} \mathrm{C}\right]$ & $\begin{array}{c}\Delta \mathrm{T}_{\text {cond, } \mathrm{NH} 3} \\
{\left[{ }^{\circ} \mathrm{C}\right]}\end{array}$ & $P_{\text {load }}$ & $\begin{array}{l}\mathrm{UA}_{\text {cond }} \\
{[\mathrm{kW} / \mathrm{K}]}\end{array}$ & & \\
\hline & $\begin{array}{c}\text { from } \\
\text { measurement }\end{array}$ & 30 & $\begin{array}{c}\text { from } \\
\text { measurement }\end{array}$ & 2.73 & & \\
\hline \multirow[b]{2}{*}{ Preheater } & $\mathrm{T}_{\mathrm{w}, \text { out }}\left[{ }^{\circ} \mathrm{C}\right]$ & $\Delta \mathrm{T}_{\text {sub }}\left[{ }^{\circ} \mathrm{C}\right]$ & $\mathrm{T}_{\text {sat }}\left[{ }^{\circ} \mathrm{C}\right]$ & & & \\
\hline & 55 or 60 & $x_{1}=2$ & $\begin{array}{c}\mathrm{T}_{\mathrm{w}, \text { out }}+5 \\
{[33]}\end{array}$ & & & \\
\hline \multirow{2}{*}{$\begin{array}{l}\text { Internal heat } \\
\text { exchanger }\end{array}$} & $\Delta \mathrm{T}_{1 \mathrm{a}-3}\left[{ }^{\circ} \mathrm{C}\right]$ & & & & & \\
\hline & 20 [34] & & & & & \\
\hline \multirow{2}{*}{$\begin{array}{l}\text { Solution } \\
\text { pump }\end{array}$} & $\eta_{\text {is,pump }}[\%]$ & $\eta_{\text {mech }}[\%]$ & & & & \\
\hline & $60[35]$ & $98[33]$ & & & & \\
\hline
\end{tabular}

\subsubsection{Absorber}

Strong and weak solutions concentrations are calculated by linear interpolation, since they are dependent on pressure and temperature according to the Othmer diagram related to the water-ammonia solution [36]. In detail, the strong solution concentration $\left(\mathrm{x}_{\text {strong }}\right)$ is correlated to the evaporator operating pressure ( $\left.\mathrm{p}_{\text {eva }}\right)$ as well as to the saturation temperature $\left(\mathrm{T}_{\mathrm{sat}}\right)$, Similarly, the weak solution concentration $\left(\mathrm{x}_{\text {weak }}\right)$ depends on the condenser pressure $\left(\mathrm{p}_{\text {cond }}\right)$ and the generator temperature $\left(\mathrm{T}_{\mathrm{gen}}\right)$. The mass balance to calculate both strong $\left(\dot{\mathrm{m}}_{\text {strong }}\right)$ and weak $\left(\dot{\mathrm{m}}_{\text {weak }}\right)$ solution mass flow rate reads as:

$$
\begin{aligned}
& \dot{\mathrm{m}}_{\text {strong }}=\frac{\dot{\mathrm{m}}_{\mathrm{NH} 3}\left(1-\mathrm{x}_{\text {weak }}\right)}{\left(\mathrm{x}_{\text {strong }}-\mathrm{x}_{\text {weak }}\right)} \\
& \dot{\mathrm{m}}_{\text {weak }}=\dot{\mathrm{m}}_{\text {strong }}-\dot{\mathrm{m}}_{\mathrm{NH} 3}
\end{aligned}
$$

The temperature at the state $c\left(\mathrm{~T}_{\mathrm{c}}\right)$ is calculated by exploiting one of the technical assumptions according to the Equation 8:

$$
\mathrm{T}_{\mathrm{c}}=\mathrm{T}_{\mathrm{f}}-\Delta \mathrm{T}_{\mathrm{c}-\mathrm{f}}
$$


where the temperature at the state $f\left(\mathrm{~T}_{\mathrm{f}}\right)$ is a function of weak solution concentration ( $\left.\mathrm{x}_{\text {weak }}\right)$ and evaporator pressure $\left(\mathrm{p}_{\mathrm{eva}}\right)$. Having said this, it can be determined by an empirical equation that has been found in literature [37].

$$
\mathrm{T}(\mathrm{p}, \mathrm{x})=\mathrm{T}_{0} \sum_{\mathrm{i}} \mathrm{a}_{\mathrm{i}}(1-\mathrm{x})^{\mathrm{m}_{\mathrm{i}}}\left[\ln \left(\frac{\mathrm{p}_{0}}{\mathrm{p}}\right)\right]^{\mathrm{n}_{\mathrm{i}}}
$$

Finally, the two-phase solution enthalpy at the state $a\left(\mathrm{~h}_{\mathrm{a}}\right)$ can be easily deduced by the energy balance equation (see Equation 10), once an adiabatic absorber has been assumed:

$$
\mathrm{h}_{\mathrm{a}}=\frac{\dot{\mathrm{m}}_{\mathrm{NH} 3} * \mathrm{~h}_{1 \mathrm{a}}+\dot{\mathrm{m}}_{\text {weak }} * \mathrm{~h}_{\mathrm{f}}+\dot{\mathrm{m}}_{\text {strong }} * \mathrm{~h}_{\mathrm{i}}-\dot{\mathrm{m}}_{\text {strong }} * \mathrm{~h}_{\mathrm{c}}}{\dot{\mathrm{m}}_{\text {strong }}}
$$

Here, the specific enthalpy at the state $c\left(\mathrm{~h}_{\mathrm{c}}\right)$ is a function of strong solution $\left(\mathrm{x}_{\text {strong }}\right)$ concentration and temperature $T_{c}$. Even in this case, numerical values can be calculated by an empirical correlation [37].

$$
\mathrm{h}(\mathrm{T}, \mathrm{x})=\mathrm{h}_{0} \sum_{\mathrm{i}} \mathrm{a}_{\mathrm{i}}\left(\frac{\mathrm{T}}{\mathrm{T}_{0}}-1\right)^{\mathrm{m}_{\mathrm{i}}} * \mathrm{x}^{\mathrm{n}_{\mathrm{i}}}
$$

\subsubsection{Generator}

The generator is characterised by a variable internal temperature a uniform temperature showing a vertical thermal gradient of $30{ }^{\circ} \mathrm{C}$, approximately. The weak solution outlet temperature at the state $d$ ( $\left.\mathrm{T}_{\text {gen,weak,out }}\right)$ and the vapour outlet temperature at the state $j$ ( $\left.\mathrm{T}_{\text {gen,vap,out }}\right)$ read as follows:

$$
\begin{aligned}
& \mathrm{T}_{\text {gen,weak,out }}=\mathrm{T}_{\text {gen }}-\Delta \mathrm{T}_{\text {gen,weak }} \\
& \mathrm{T}_{\text {gen,vap,out }}=\mathrm{T}_{\text {gen }}-\Delta \mathrm{T}_{\text {gen,vap }}
\end{aligned}
$$

Once the weak solution outlet temperature and the concentration at the state $d$ are known, the specific enthalpy $\left(\mathrm{h}_{\mathrm{d}}=\mathrm{h}_{\mathrm{f}}\right)$ is calculated by Eq11. Differently, at the state $j$, the ammonia specific enthalpy $\left(h_{j}\right)$ refers to the vapor state, so that a further empirical correlation has been used (see Equation 14) [37].

$$
\mathrm{h}(\mathrm{T}, \mathrm{y})=\mathrm{h}_{0} \sum_{\mathrm{i}} \mathrm{a}_{\mathrm{i}}\left(1-\frac{\mathrm{T}}{\mathrm{T}_{0}}\right)^{\mathrm{m}_{\mathrm{i}}} *(1-\mathrm{y})^{\frac{\mathrm{n}_{\mathrm{i}}}{4}}
$$

In accordance with literature [34], it is reasonable to assume that the ammonia mass flow rate $\left(\dot{\mathrm{m}}_{\mathrm{j}}\right)$, in the vapour state leaving the generator is characterised by a mass fraction equal to $0.92 \mathrm{~kg}_{\text {ammonia }} / \mathrm{kg}$ solution. Thereafter, having fixed the heat exchanger effectiveness ( $\left.\varepsilon_{\text {exchange }}\right)$, the energy supplied by the burner $\left(\mathrm{P}_{\text {fuel }}\right)$ can be determined by the Equation 15 .

$$
\mathrm{P}_{\text {fuel }}=\frac{\dot{\mathrm{m}}_{\mathrm{j}} * \mathrm{~h}_{\mathrm{j}}+\dot{\mathrm{m}}_{\mathrm{weak}} * \mathrm{~h}_{\mathrm{d}}-\dot{\mathrm{m}}_{\text {strong }} * \mathrm{~h}_{\mathrm{c}}-\dot{\mathrm{m}}_{\mathrm{k}} * \mathrm{~h}_{\mathrm{k}}}{\varepsilon_{\text {exchange }} * \eta_{\text {burner }}}
$$

The exhaust gas mass flow rate ( $\left.\dot{\mathrm{m}}_{\text {exhaust }}\right)$ along with the fuel mass flow rate $\left(\dot{\mathrm{m}}_{\text {fuel }}\right)$ are calculated by the energy balance within the combustion chamber.

$$
\dot{\mathrm{m}}_{\text {exhaust }}=\frac{\mathrm{P}_{\text {fuel }}}{\text { Cp }_{\text {exhaust }} *\left[\mathrm{~T}_{\text {comb }}-\left(\mathrm{T}_{\text {gen }}+10\right)\right]}
$$




$$
\begin{gathered}
\mathrm{T}_{\text {comb }}=\left(\mathrm{T}_{\text {gen }}+10\right)+\frac{\mathrm{LHV}_{\text {fuel }} * \eta_{\text {burner }}}{\left(\alpha_{\mathrm{st}} * \lambda+1\right) * \mathrm{Cp}_{\text {exhaust }}} \\
\dot{\mathrm{m}}_{\text {fuel }}=\frac{\mathrm{P}_{\text {fuel }}}{\mathrm{LHV}_{\text {fuel }} * \eta_{\text {burner }}}
\end{gathered}
$$

The specific heat at constant pressure of the exhaust gases ( $c_{\mathrm{p}}$, exhaust $)$ is calculated by the weighted average of the specific heat at constant pressure related to each combustion byproduct $\left(\mathrm{c}_{\mathrm{p}, \mathrm{i}}\right)$. For calculations, a simplified exhaust gas composition has been considered, where $\left(\mathrm{w}_{\mathrm{i}}\right)$ is the mass fraction and only $\mathrm{H}_{2} \mathrm{O}, \mathrm{CO}_{2}, \mathrm{~N}_{2}$ e $\mathrm{O}_{2}$ have been accounted for. In addition, the specific heat at constant pressure values have been calculated as a temperature dependent function by means of Langen binomial formula.

$$
\begin{aligned}
& \mathrm{c}_{\mathrm{p}, \text { exhaust }}=\sum_{\mathrm{i}} \mathrm{c}_{\mathrm{p}, \mathrm{i}} * \mathrm{w}_{\mathrm{i}} \\
& \mathrm{c}_{\mathrm{p} . \mathrm{i}}=\mathrm{a}+\mathrm{b} * \mathrm{~T}(\mathrm{~K})
\end{aligned}
$$

In the end, Table 3 summarises some of the most significant $\mathrm{H}_{2} \mathrm{NG}$ thermophysical properties when more hydrogen is added to the blend: the normal density, the Lower Heating Value by mass and by volume ( $\left.\mathrm{LHV}_{\text {fuel }}\right)$ and the stoichiometric air to fuel ratio $\left(\alpha_{\mathrm{st}}\right)$.

Table 3. Hydro methane blends thermophysical properties

\begin{tabular}{|c|c|c|c|c|}
\hline $\begin{array}{c}\text { Hydrogen fraction } \\
\text { by volume [\%] }\end{array}$ & $\boldsymbol{\rho}\left[\mathbf{k g} / \mathbf{N m}^{\mathbf{3}}\right]$ & $\mathbf{L H V}$ fuel $[\mathbf{k j} / \mathbf{k g}]$ & $\mathbf{L H V}_{\text {fuel }}\left[\mathbf{k j} / \mathbf{N m} \mathbf{m}^{\mathbf{3}}\right]$ & $\boldsymbol{\alpha}_{\text {st }}[\mathbf{k g} / \mathbf{k g}]$ \\
\hline $0 \%$ & 0.7138 & $50,000.00$ & $35,691.98$ & 17.391 \\
\hline $5 \%$ & 0.6826 & $50,467.32$ & $34,449.45$ & 17.504 \\
\hline $10 \%$ & 0.6513 & $50,979.45$ & $33,206.92$ & 17.656 \\
\hline
\end{tabular}

\subsubsection{Rectifier}

Within this component, the rectified flow composition $\left(\mathrm{x}_{\mathrm{k}}\right)$ is correlated to the condenser operating pressure $\left(\mathrm{p}_{\text {cond }}\right)$ together with the rectifier temperature $\left(\mathrm{T}_{\text {rect }}\right)$. As reported in the previous subsection 2.1.2, that values has been deduced by the use of the Othmer diagram [36]. Starting from the mass balance it is possible to calculate the rectified solution mass flow rate $\left(\dot{\mathrm{m}}_{\mathrm{k}}\right)$ flowing back to the generator by the Equation 21 . Then, the strong solution specific enthalpy value $\left(\mathrm{h}_{\mathrm{i}}\right)$ when it leaves the rectifier (i.e. the state $i$ ) can be deduced by rearranging the rectifier energy balance according to the Equation 22.

$$
\begin{gathered}
\dot{\mathrm{m}}_{\mathrm{k}}=\frac{\dot{\mathrm{m}}_{\mathrm{j}}\left(1-\mathrm{y}_{\mathrm{i}}\right)}{\left(1-\mathrm{x}_{\mathrm{k}}\right)} \\
\mathrm{h}_{\mathrm{i}}=\frac{\dot{\mathrm{m}}_{\mathrm{j}} * \mathrm{~h}_{\mathrm{j}}-\dot{\mathrm{m}}_{\mathrm{k}} * \mathrm{~h}_{\mathrm{k}}+\dot{\mathrm{m}}_{\text {strong }} * \mathrm{~h}_{\mathrm{h}}-\dot{\mathrm{m}}_{\mathrm{NH} 3} * \mathrm{~h}_{2}}{\dot{\mathrm{m}}_{\text {strong }}}
\end{gathered}
$$

It is important to point out that the specific enthalpy at the state $2\left(\mathrm{~h}_{2}\right)$ and $k\left(\mathrm{~h}_{\mathrm{k}}\right)$ have been already determined by the Equation 14 (assuming $\mathrm{y}=1$ ) and the Equation 11, respectively. 


\subsubsection{Condenser}

The ammonia mass flow rate $\left(\dot{\mathrm{m}}_{\mathrm{NH} 3}\right)$ is immediately calculated starting from the thermal power, which is the first input for the GAHP model. The condenser energy balance takes into account both sensible and latent heat transfer, so that the ammonia mass flow rate reads as:

$$
\dot{\mathrm{m}}_{\mathrm{NH} 3}=\frac{\mathrm{P}_{\text {load }}}{\left(\mathrm{c}_{\mathrm{p}, \mathrm{NH} 3} * \Delta \mathrm{T}_{\text {cond, } \mathrm{NH} 3}\right)+\mathrm{l}_{\mathrm{h}, \mathrm{NH} 3}}
$$

The evaporator operating pressure ( $\mathrm{p}_{\text {cond }}$ ) has been determined using the same approach which has been applied to the condenser. Indeed, $\left(\mathrm{T}_{3}\right)$ can be evaluated by the $\varepsilon$-NTU method and the operating pressure value comes out by manipulating the Antoine equation (see Equation 3).

$$
\begin{gathered}
\mathrm{T}_{3}=\frac{\mathrm{T}_{\mathrm{w}_{,} \text {out }}-\mathrm{T}_{\mathrm{w}, \text { preheater,out }} * \mathrm{e}^{-\mathrm{NTU}_{\text {cond }}}}{\left(1-\mathrm{e}^{-\mathrm{NTU}_{\mathrm{c}}}\right)} \\
\mathrm{NTU}_{\text {cond }}=\frac{\mathrm{UA}_{\text {cond }}}{\dot{\mathrm{m}}_{\mathrm{w}, \text { cond }} * \mathrm{Cp}_{\mathrm{w}}} \\
\dot{\mathrm{m}}_{\mathrm{w}, \text { cond }}=\frac{\mathrm{P}_{\text {load }}}{\mathrm{Cp}_{\mathrm{w}} * \Delta \mathrm{T}_{\mathrm{w}, \text { load }}}
\end{gathered}
$$

As a consequence, once $p_{\text {cond }}$ e $T_{3}$ are known the ammonia specific enthalpy value $\left(h_{3}\right)$ downstream the condenser can be easily evaluated.

\subsubsection{Preheater}

The strong solution temperature at the state $g\left(\mathrm{~T}_{\mathrm{g}}\right)$ is defined as follows:

$$
\mathrm{T}_{\mathrm{g}}=\mathrm{T}_{\text {sat }}-\Delta \mathrm{T}_{\text {sub }}
$$

It is noteworthy that $\mathrm{T}_{\mathrm{g}}$ and $\mathrm{x}_{\text {strong }}$ values are required in order to compute the specific enthalpy at the state $g\left(\mathrm{~h}_{\mathrm{g}}\right)$ by means of the Equation 11. Thereafter, from the heat exchanger energy balance, referred to the cold side, the preheater outlet water temperature $\left(\mathrm{T}_{\mathrm{w} \text {,preheater,out }}\right)$ reads as:

$$
\mathrm{T}_{\mathrm{w}, \text { preheater,out }}=\left(\mathrm{T}_{\mathrm{w}, \text { out }}-\Delta \mathrm{T}_{\mathrm{w}, \text { load }}\right)+\frac{\mathrm{Q}_{\text {solution }}}{\mathrm{Cp}_{\mathrm{w}} * \mathrm{~m}_{\mathrm{w}, \text { cond }}}
$$

Where the heat release from solution is calculated according to the Equation 29.

$$
\mathrm{Q}_{\text {solution }}=\dot{\mathrm{m}}_{\text {strong }}\left(\mathrm{h}_{\mathrm{a}}-\mathrm{h}_{\mathrm{g}}\right)
$$

\subsubsection{Internal heat exchanger}

The regenerative heat exchanger is the counter-flow type and it has been modelled in adiabatic conditions.

$$
\mathrm{T}_{1 \mathrm{a}}=\mathrm{T}_{3}-\Delta \mathrm{T}_{1 \mathrm{a}-3}
$$


Knowing the pressure value at the state $1 a$ (i.e. $\mathrm{p}_{1 \mathrm{a}}=\mathrm{p}_{\text {cond }}$ ), along with the temperature one $\left(T_{1 a}\right)$, it is possible to calculate the corresponding specific enthalpy value $\left(\mathrm{h}_{1 \mathrm{a}}\right)$. Thus, the specific enthalpy at the state $3 a\left(\mathrm{~h}_{3 \mathrm{a}}\right)$ derives from the energy balance in accordance with the Equation 31.

$$
\mathrm{h}_{3 \mathrm{a}}=\mathrm{h}_{3}+\mathrm{h}_{1}-\mathrm{h}_{1 \mathrm{a}}
$$

\subsubsection{Expansion valve}

The expansion valve modelling it is very easy. Indeed, it is well known how the thermodynamic transformation can be considered isenthalpic. Having said this, the liquid pure ammonia flow, passing through the valve, it lowers its temperature and pressure from ( $\left.\mathrm{p}_{\text {cond }}\right)$ up to $\left(\mathrm{p}_{\mathrm{eva}}\right)$. Therefore, the ammonia inlet thermodynamic conditions to the evaporator are now completely determined.

\subsubsection{Solution pump}

Thermodynamic work associated the solution pump ( $\left.\mathrm{W}_{\text {sol,pump }}\right)$ is useful to evaluate the liquid strong solution specific enthalpy at the state $h$. To do so, the Equation 32 can be used, once some technical assumption on the isentropic and mechanical efficiency are made together with the strong solution specific volume $\left(v_{\text {sol }}\right)$ calculation. This latter is dependent on the mass fraction and it has been calculated by numerical fit reported in literature [37].

$$
\mathrm{W}_{\text {sol,pump }}=\frac{v_{\text {sol }} * \dot{\mathrm{m}}_{\text {strong }}\left(\mathrm{p}_{\text {cond }}-\mathrm{p}_{\text {eva }}\right)}{\eta_{\text {is,pump }} * \eta_{\text {mech }}}
$$

\section{Results and discussion}

The aim of this research project is to build and validate the GAHP mathematical model when that machine runs in actual operating conditions, and it is fuelled with unconventional gaseous fuels. The model validation process has been carried out collecting and filtering all of the time series data related to 4 output parameters: the outlet water temperature from the evaporator, the subtracted thermal power from cold heat sink, the fuel consumption and the GAHP efficiency in terms of GUE. By comparing the predicted values with the measured ones, relative standard errors and standard errors associated to those parameters have been computed for each set up. Referring to Figures 2,3 and 4 it is possible to state that the average relative standard associated to $\mathrm{T}_{\text {outevap }}$ is lower than $2.5 \%$ when the GAHP is fuelled with NG. It is worth of noticing that the depicted data in those charts correspond to different load conditions at the end-user side. On the contrary, it ranges between $2.5 \%$ and $3.96 \%$ when $\mathrm{H}_{2} \mathrm{NG}$ at $5 \%$ and $10 \%$ by volume of hydrogen fraction have been burnt. 


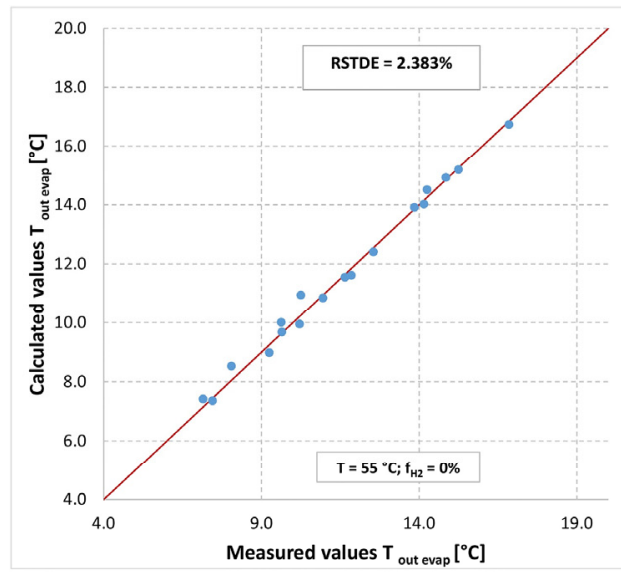

a)

Fig. 2. Measured vs. predicted values of outlet water temperature of evaporator: a) $0 \%$ vol. of $\mathrm{H}_{2}$ fraction, supply water temperature equal to $55^{\circ} \mathrm{C}$; b) $0 \%$ vol. of $\mathrm{H}_{2}$ fraction, supply water temperature equal to $60^{\circ} \mathrm{C}$.

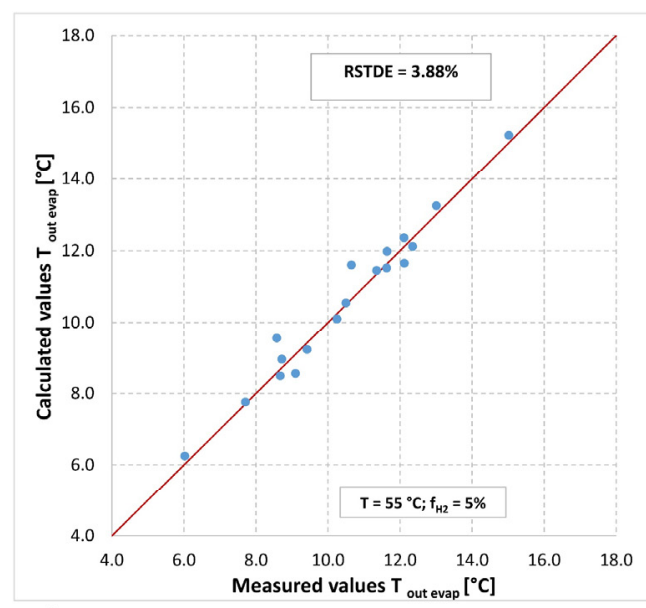

a)

Fig. 3. Measured vs. predicted values of outlet water fraction, supply water temperature equal to $55^{\circ} \mathrm{C}$; b) $5 \%$ vol. of $\mathrm{H}_{2}$ fraction, supply water temperature equal to $60^{\circ} \mathrm{C}$.

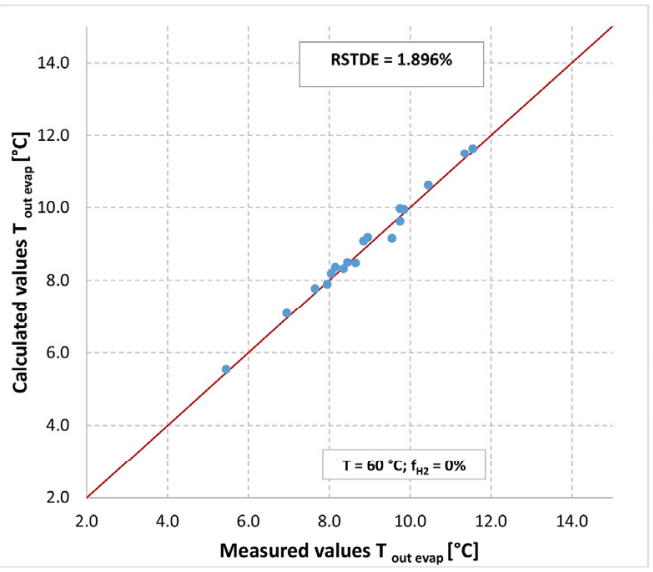

b)

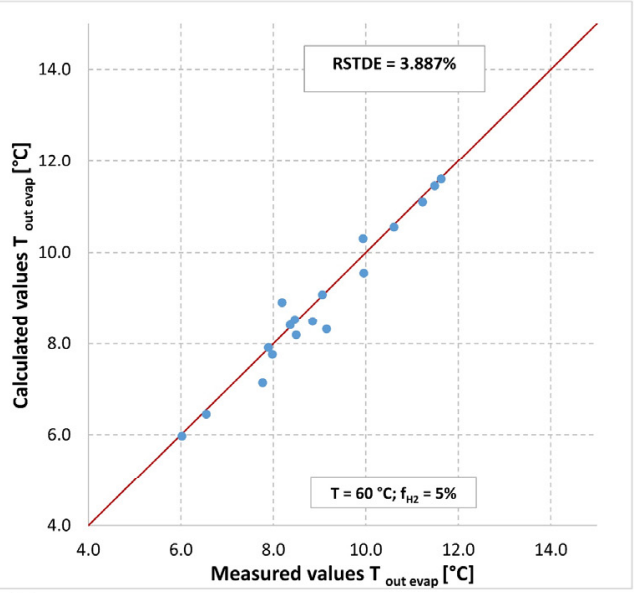

b) 


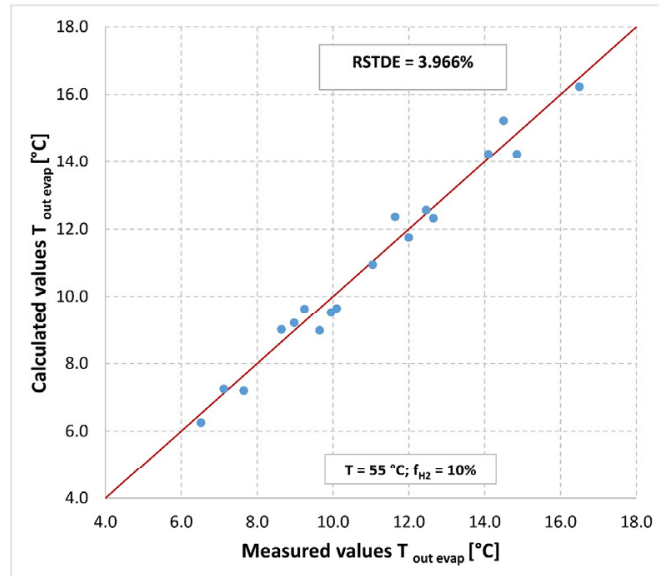

a)

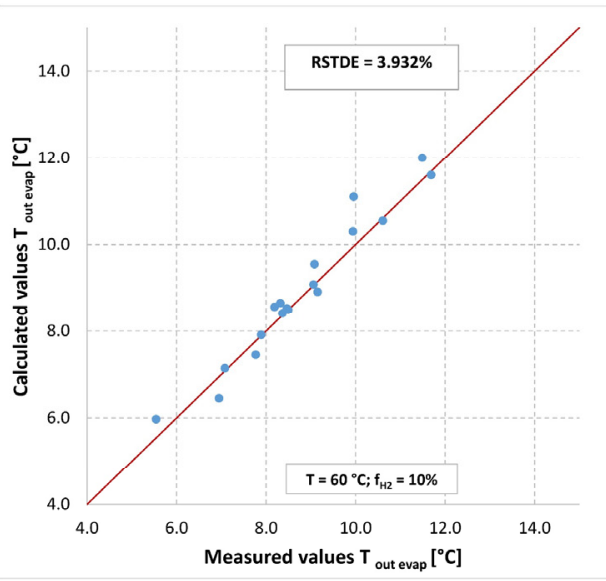

b)

Fig. 4. Measured vs. predicted values of outlet water temperature of evaporator: a) $10 \%$ vol. of $\mathrm{H}_{2}$ fraction, supply water temperature equal to $55^{\circ} \mathrm{C}$; b) $10 \%$ vol. of $\mathrm{H}_{2}$ fraction, supply water temperature equal to $60^{\circ} \mathrm{C}$.

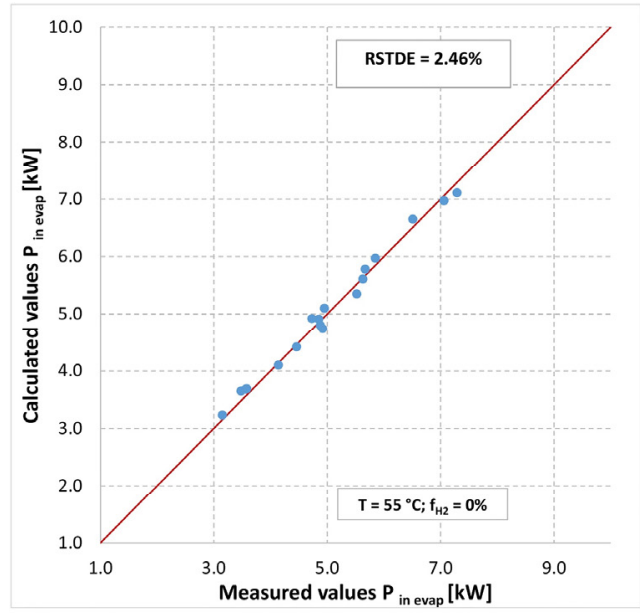

a)

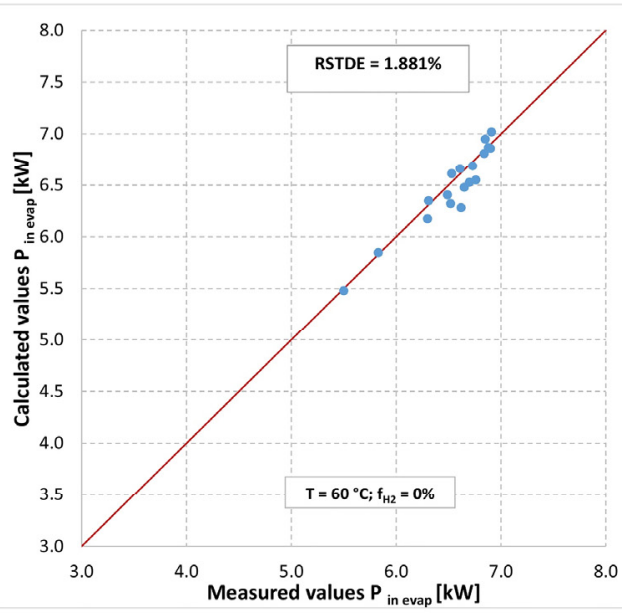

b)

Fig. 5. Measured vs. predicted values of thermal power at the evaporator: a) $0 \%$ vol. of $\mathrm{H}_{2}$ fraction, supply water temperature equal to $55^{\circ} \mathrm{C}$; b) $0 \%$ vol. of $\mathrm{H}_{2}$ fraction, supply water temperature equal to $60^{\circ} \mathrm{C}$. 


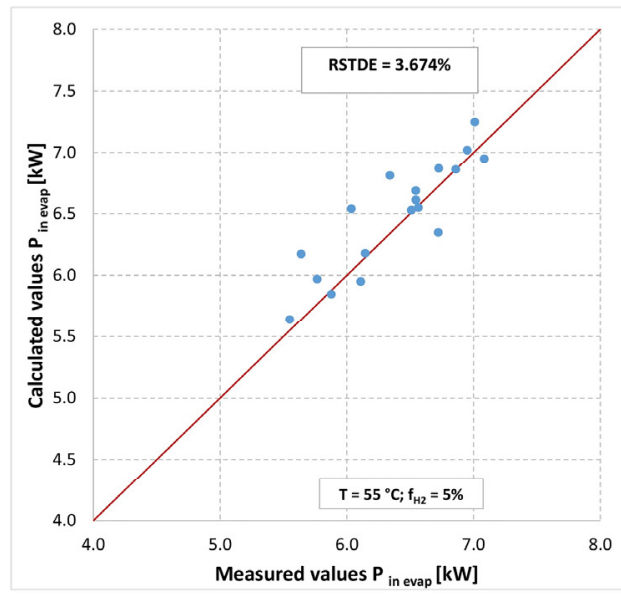

a)

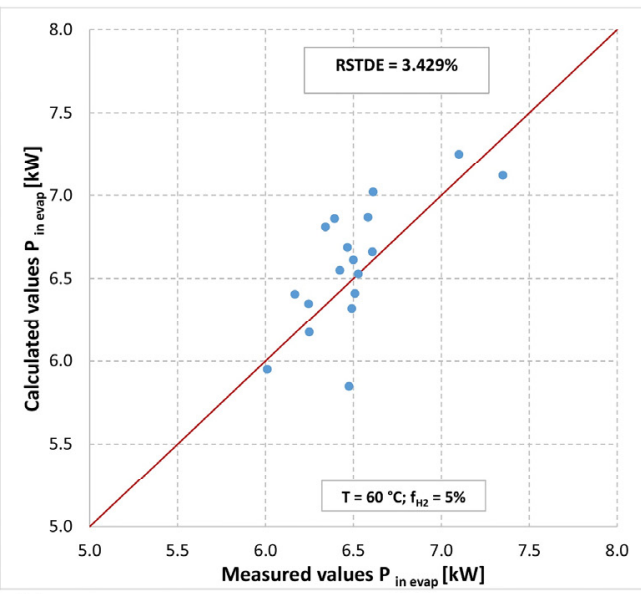

b)

Fig. 6. Measured vs. predicted values of thermal power at the evaporator: a) $5 \%$ vol. of $\mathrm{H}_{2}$ fraction, supply water temperature equal to $55^{\circ} \mathrm{C}$; b) $5 \%$ vol. of $\mathrm{H}_{2}$ fraction, supply water temperature equal to $60^{\circ} \mathrm{C}$.

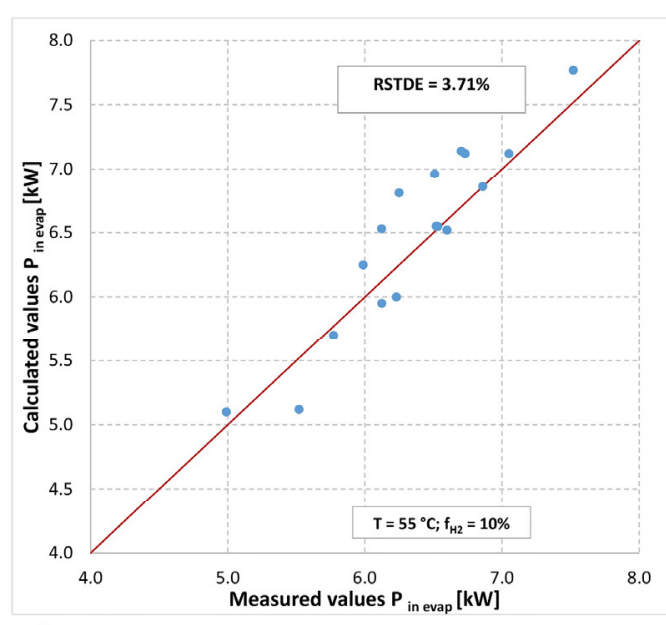

a)

Fig. 7. Measured vs. predicted values of thermal power at the evaporator: a) $10 \%$ vol. of $\mathrm{H}_{2}$ fraction, supply water temperature equal to $55^{\circ} \mathrm{C}$; b) $10 \%$ vol. of $\mathrm{H}_{2}$ fraction, supply water temperature equal to $60^{\circ} \mathrm{C}$.

In regards of subtracted power at the evaporator, Figures 5, 6 and 7 depict the validation results. Specifically, it possible to notice how the model fits quite well the measured data when NG is used. Indeed, the relative standard error is lower than $2.5 \%$. Conversely, as the hydrogen fraction increases the relative standard error enhances as well, but it does not exceed $4 \%$. This is due to the fact that the hydrogen addiction slightly rises the combustion temperature within the burner. Nevertheless, that effect is mitigated by the higher values of relative equivalence ratio $(\lambda)$. Consequently, the generator inner temperature $\left(T_{\text {gen }}\right)$ increases as well, modifying the thermodynamic conditions at the rectifier. It entails that the ammonia vapour flow rate $\left(\dot{\mathrm{m}}_{\mathrm{NH} 3}\right)$ slightly decreases, so that both the condenser and evaporator energy 
balance are affected by that behaviour. To mitigate the discrepancy between simulated and predicted data, a variable global heat transfer coefficient $U$, related to both heat exchangers (i.e. condenser and evaporator), should be implemented in the model. In so doing, calculated outputs by the $\varepsilon$-NTU method application will fit better the measured parameters. Additionally, the subtracted power from cold heat sink is much more influenced by those issues. Indeed, an error associated to the saturation temperature within the evaporator (and consequently on $p_{\text {eva }}$ ) implies a different latent heat value, penalising the energy balance.

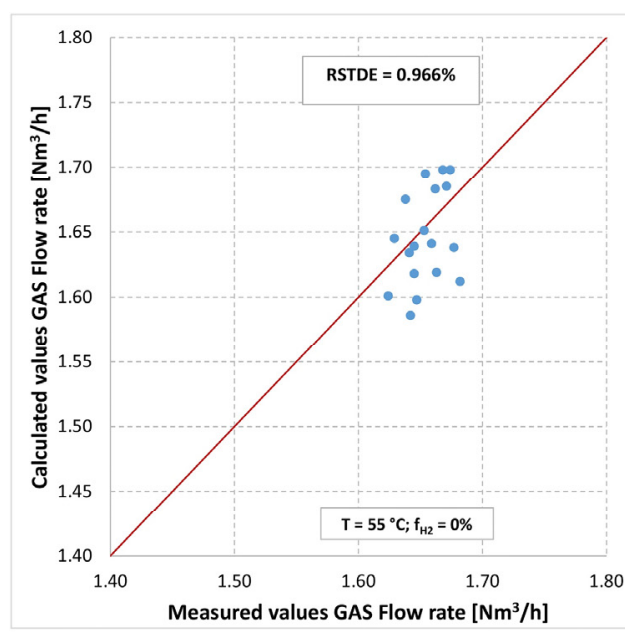

a)

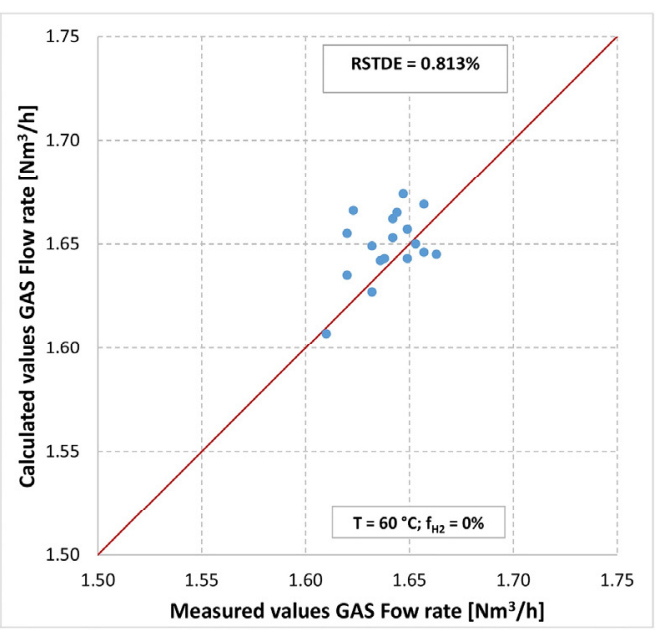

b)

Fig. 8. Measured vs. predicted GAS flow rate values: a) $0 \%$ vol. of $\mathrm{H}_{2}$ fraction, supply water temperature equal to $55^{\circ} \mathrm{C}$; b) $0 \%$ vol. of $\mathrm{H}_{2}$ fraction, supply water temperature equal to $60^{\circ} \mathrm{C}$.

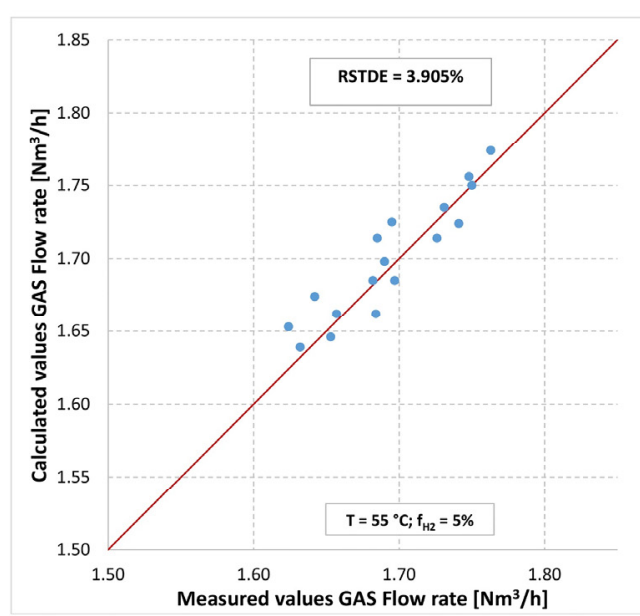

a)

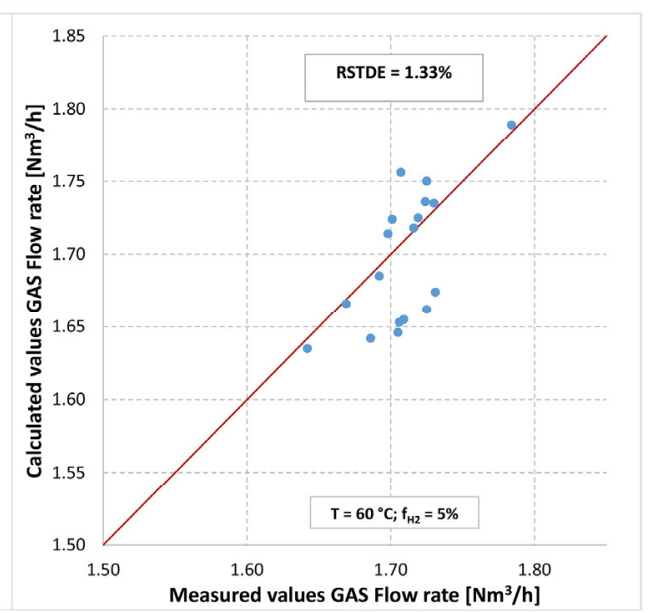

b)

Fig. 9. Measured vs. predicted GAS flow rate values: a) 5\% vol. of $\mathrm{H}_{2}$ fraction, supply water temperature equal to $55^{\circ} \mathrm{C}$; b) $5 \%$ vol. of $\mathrm{H}_{2}$ fraction, supply water temperature equal to $60^{\circ} \mathrm{C}$. 


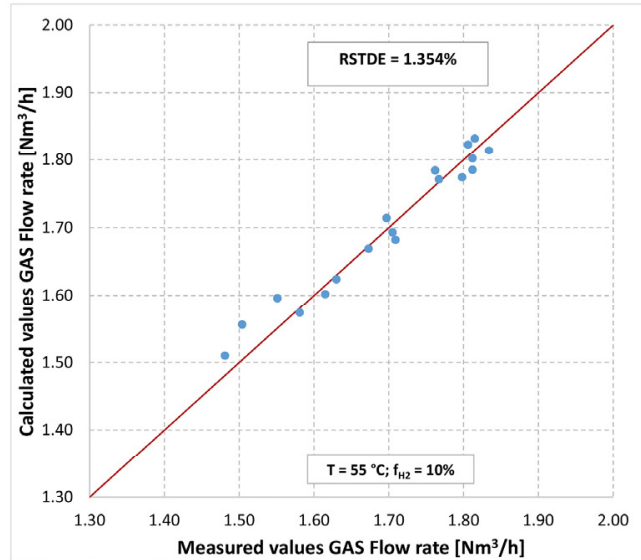

a)

Fig. 10. Measured vs. predicted GAS flow rate values: a) $10 \%$ vol. of $\mathrm{H}_{2}$ fraction, supply water temperature equal to $55^{\circ} \mathrm{C}$; b) $10 \%$ vol. of $\mathrm{H}_{2}$ fraction, supply water temperature equal to $60^{\circ} \mathrm{C}$.

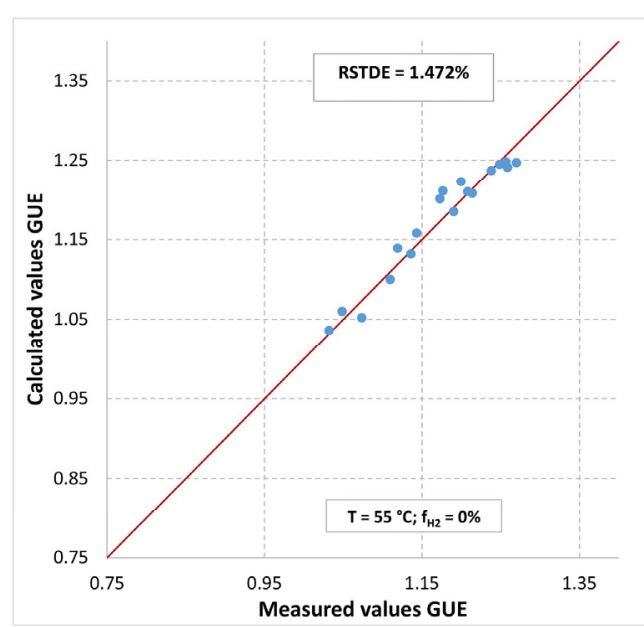

a)

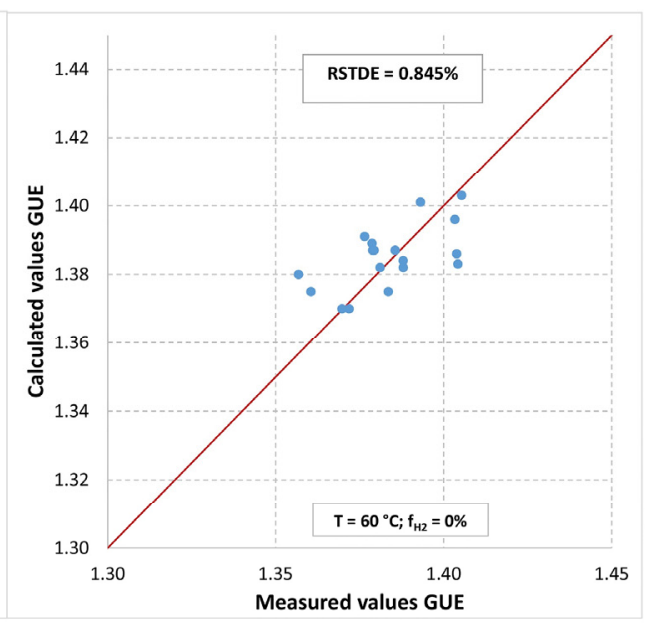

b)

Fig. 11. Measured vs. predicted GUE values: a) $0 \%$ vol. of $\mathrm{H}_{2}$ fraction, supply water temperature equal to $55^{\circ} \mathrm{C}$; b) $0 \%$ vol. of $\mathrm{H}_{2}$ fraction, supply water temperature equal to $60^{\circ} \mathrm{C}$. 


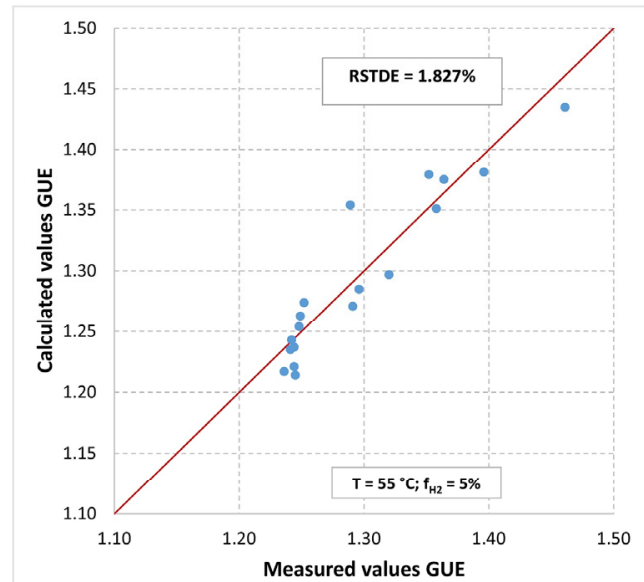

a)

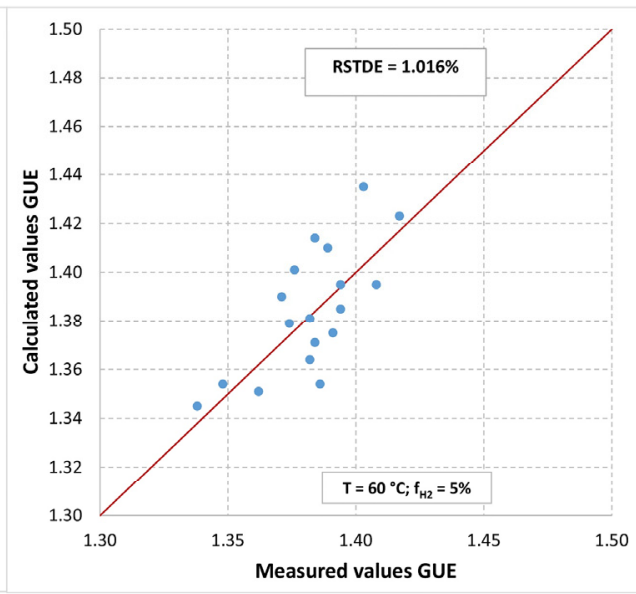

b)

Fig. 12. Measured vs. predicted GUE values: a) $5 \%$ vol. of $\mathrm{H}_{2}$ fraction, supply water temperature equal to $55^{\circ} \mathrm{C}$; b) $5 \%$ vol. of $\mathrm{H}_{2}$ fraction, supply water temperature equal to $60^{\circ} \mathrm{C}$.

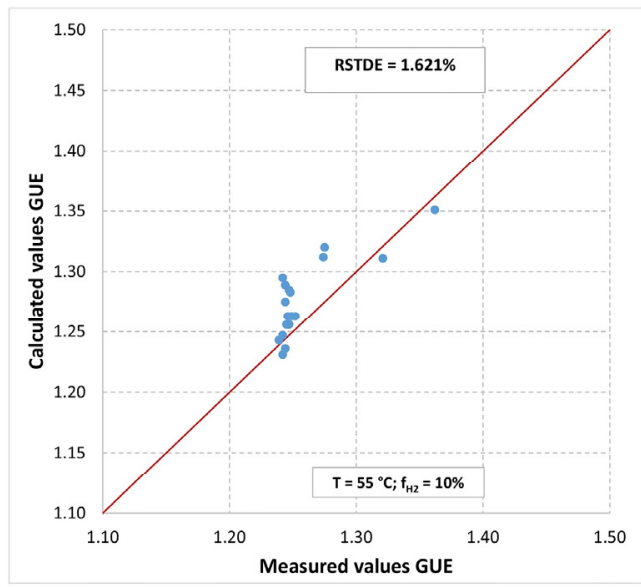

a)

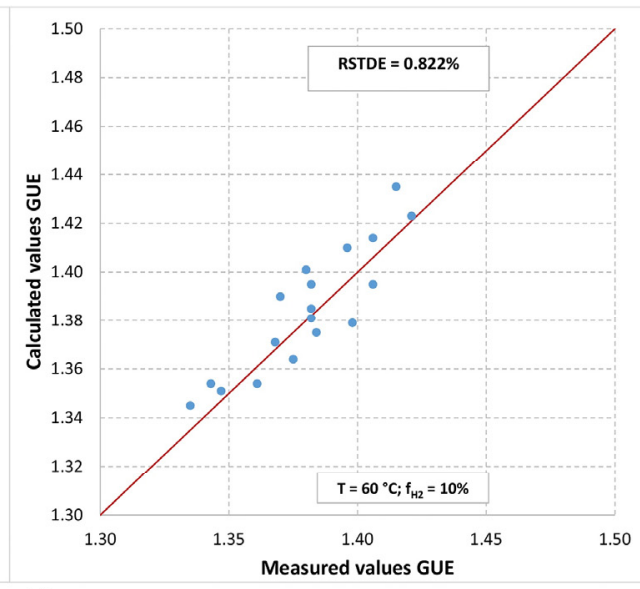

b)

Fig. 13. Measured vs. predicted GUE values: a) $10 \%$ vol. of $\mathrm{H}_{2}$ fraction, supply water temperature equal to $55^{\circ} \mathrm{C}$; b) $10 \%$ vol. of $\mathrm{H}_{2}$ fraction, supply water temperature equal to $60^{\circ} \mathrm{C}$.

Thus, Figures 8, 9 and 10 show the comparison between measured and predicted values related to the fuel consumption. Feeding the GAHP by $\mathrm{H}_{2} \mathrm{NG}$ mixtures, the relative standard error is much more limited than in the previous cases. Anyway, the absolute standard errors on fuel consumption (which are summarised in Table 4.) are just above the instruments' accuracy band. The quantitative analysis shows that the relative standard error is $3.9 \%$ when $5 \%$ vol. of hydrogen fraction has been used. In detail, the model tends to overestimate the actual measurements. This is due to the fact that the latest experimental tests (with supply water temperature equal to $55^{\circ} \mathrm{C}$ ) were carried over the end of March and the beginning of April. The increase in the outdoor environmental temperature implies a slight air heating up within the combustion chamber, favouring the fuel flow rate reduction. The model structure does not account for the inlet air temperature (as shown in paragraph 2.1.3) and therefore the measurements are affected by error. In the end, Figures 11, 12 and 13 depict data sets related to the GAHP First Law Efficiency in terms of GUE, as defined in Equation 1. From the analytical point of view, the GUE is a as a ratio between two quantities. In the proposed 
model, the numerator $\left(\mathrm{P}_{\text {load }}\right)$ is an input value for all operating conditions, therefore it cannot be affected by error. As a consequence, the unique parameter contributing to the error propagation is the denominator $\left(\mathrm{P}_{\text {fuel }}\right)$. For that reason, the GUE relative standard error is characterised by a hyperbolic trend depending on the fuel flow rate error. Indeed, the larger the fuel consumption standard error, the lower the GUE standard error is. Having said this, it is possible to understand why the highest relative standard error (i.e. 1.827\%) has been registered when GAHP provides hot water at $55{ }^{\circ} \mathrm{C}$ and it is fuelled with $\mathrm{H} 2 \mathrm{NG}$ at $5 \%$ vol. of hydrogen content. Table 4 shows the standard errors in absolute terms. Those ones can be compared to the band accuracy associated to each instrument reported in Table 1.

Table 4. Standard error of the main outputs

\begin{tabular}{|c|c|c|c|c|}
\hline \multirow{2}{*}{$\mathrm{T}_{\mathrm{w}, \text { out,evaporator }\left[{ }^{\circ} \mathrm{C}\right]}$} & $\mathbf{T}_{\mathbf{w}, \mathbf{o u t}, \text { condenser }}$ & $\mathbf{0 \%} \mathbf{H}_{\mathbf{2}}$ & $\mathbf{5 \%} \mathbf{H}_{\mathbf{2}}$ & $\mathbf{1 0 \%} \mathbf{H}_{\mathbf{2}}$ \\
\cline { 2 - 5 } & $55^{\circ} \mathrm{C}$ & 0.276 & 0.411 & 0.433 \\
\hline \multirow{2}{*}{$\mathrm{P}_{\text {in,evaporator }}[\mathrm{kW}]$} & $60^{\circ} \mathrm{C}$ & 0.169 & 0.345 & 0.351 \\
\cline { 2 - 5 } & $55^{\circ} \mathrm{C}$ & 0.124 & 0.238 & 0.244 \\
\hline \multirow{2}{*}{ Gas flow rate $\left[\mathrm{Nm}{ }^{3}\right]$} & $50^{\circ} \mathrm{C}$ & 0.122 & 0.225 & 0.165 \\
\cline { 2 - 5 } & $55^{\circ} \mathrm{C}$ & 0.016 & 0.066 & 0.023 \\
\hline \multirow{2}{*}{ GUE } & $50^{\circ} \mathrm{C}$ & 0.013 & 0.022 & 0.026 \\
\cline { 2 - 5 } & $55^{\circ} \mathrm{C}$ & 0.017 & 0.024 & 0.021 \\
\hline
\end{tabular}

\section{Conclusions}

In this paper the authors propose a numerical model to simulate the GAHP behaviour when it is fuelled with hydrogen enriched natural gas blends. The experimental campaign allowed on one hand to validate the MATLAB Simulink model, on the other hand to demonstrate the suitability of hydrogen use with commercial devices. From data analysis emerges that no penalties and drawbacks occur. Then, the validation process shows how the model fits well the real data since the relative standard errors range between $0.82 \%$ and $2.46 \%$ for natural gas feeding case. Once growing hydrogen fractions are used, those errors on the estimated parameters varies between $0.82 \%$ and $3.97 \%$. From an energy point of view, the hydrogen addition does not visibly influence the machine performance. This is due to the fact that the tested GAHP heat recovery architecture is not able to exploit latent heat by condensing out the exhaust gas water content. It is worth of noticing that the hydrogen cofiring with other fossil fuels allows to attain higher water concentration within the exhaust gases. Hence, in order to improve the GAHP efficiency, so as to fruitfully exploit the hydrogen benefits, new layouts should be analysed and developed. 


\section{Nomenclature}

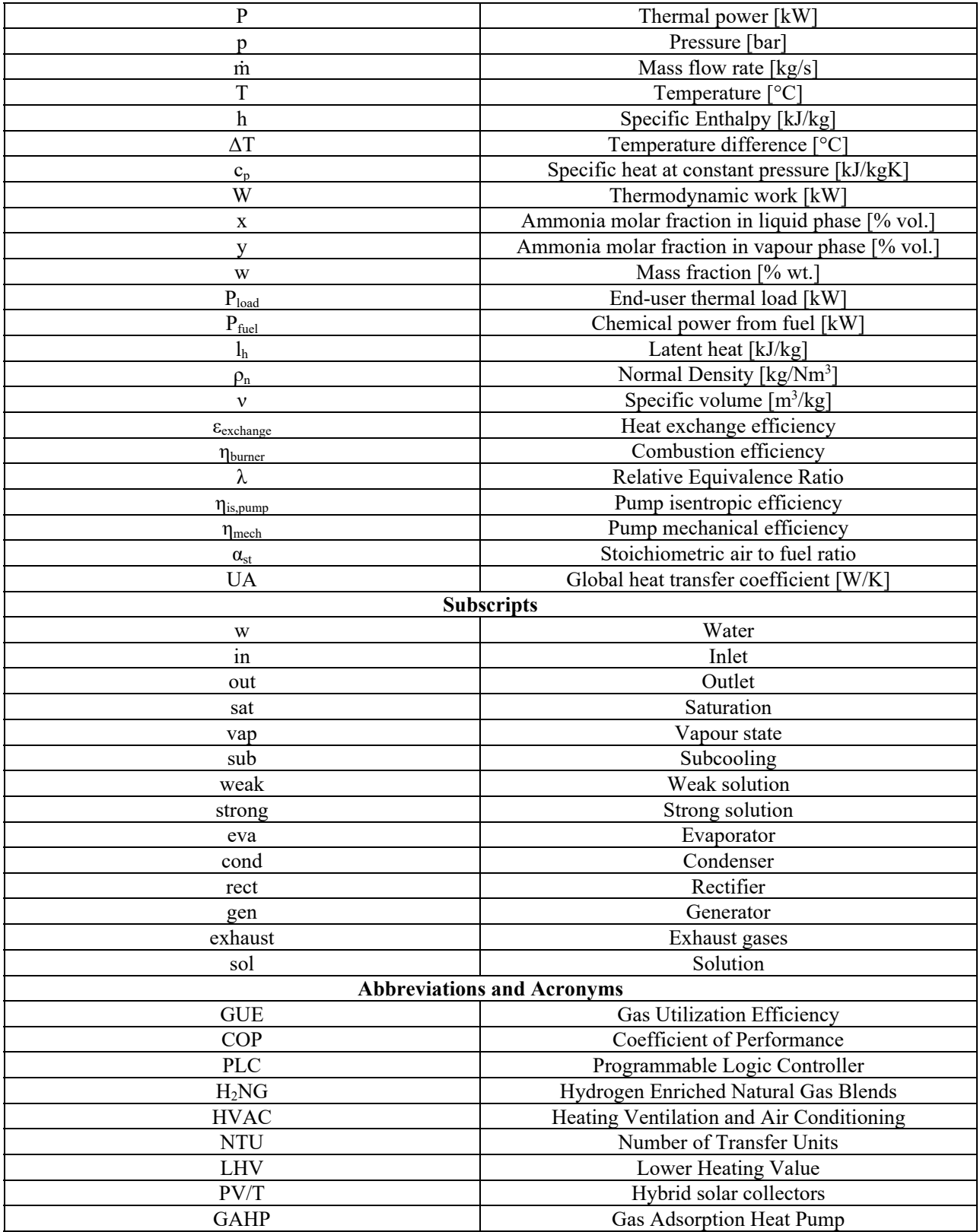

\section{Acknowledgements}

The authors would like to express their gratitude to Department of Astronautics Electric and Energy Engineering for its availability and cooperation. Finally, funding and support by "Progetti di Ricerca Medi 2016", which is a research grant program funded by Sapienza University of Rome, is gratefully acknowledged. 


\section{References}

1. Guandalini, G.; Robinius, M.; Grube, T.; Campanari, S.; Stolten, D. Long-term power-to-gas potential from wind and solar power: A country analysis for Italy. Int. J. Hydrogen Energy 2017, 42, 13389-13406, doi:10.1016/j.ijhydene.2017.03.081.

2. $\quad$ Lyseng, B.; Niet, T.; English, J.; Keller, V.; Palmer-Wilson, K.; Robertson, B.; Rowe, A.; Wild, P. System-level power-to-gas energy storage for high penetrations of variable renewables. Int. J. Hydrogen Energy 2018, 43, 1966-1979, doi:10.1016/j.ijhydene.2017.11.162.

3. Groppi, D.; Astiaso Garcia, D.; Lo Basso, G.; Cumo, F.; De Santoli, L. Analysing economic and environmental sustainability related to the use of battery and hydrogen energy storages for increasing the energy independence of small islands. Energy Convers. Manag. 2018, 177, 64-76, doi:10.1016/j.enconman.2018.09.063.

4. Nastasi, B.; Lo Basso, G. Power-to-Gas integration in the Transition towards Future Urban Energy Systems. Int. J. Hydrogen Energy 2017, 42, 23933-23951, doi:10.1016/j.ijhydene.2017.07.149.

5. Nastasi, B.; Lo Basso, G.; Astiaso Garcia, D.; Cumo, F.; de Santoli, L. Power-togas leverage effect on power-to-heat application for urban renewable thermal energy systems. Int. J. Hydrogen Energy 2018, 23076-23090, doi:10.1016/j.ijhydene.2018.08.119.

6. Ajanovic, A.; Hiesl, A.; Haas, R. On the role of storage for electricity in smart energy systems. Energy 2020, 200, doi:10.1016/j.energy.2020.117473.

7. Lund, H.; Duic, N.; Østergaard, P.A.; Mathiesen, B.V. Perspectives on Smart Energy Systems from the SES4DH 2018 conference. Energy 2020, 190.

8. Bačeković, I.; Østergaard, P.A. Local smart energy systems and cross-system integration. Energy 2018, 151, 812-825, doi:10.1016/j.energy.2018.03.098.

9. Bačeković, I.; Østergaard, P.A. A smart energy system approach vs a nonintegrated renewable energy system approach to designing a future energy system in Zagreb. Energy 2018, 155, 824-837, doi:10.1016/j.energy.2018.05.075.

10. Mancini, F.; Basso, G. Lo How climate change affects the building energy consumptions due to cooling, heating, and electricity demands of Italian residential sector. Energies 2020, 13, doi:10.3390/en13020410.

11. Mancini, F.; Romano, S.; Lo Basso, G.; Cimaglia, J.; de Santoli, L. How the Italian Residential Sector Could Contribute to Load Flexibility in Demand Response Activities: A Methodology for Residential Clustering and Developing a Flexibility Strategy. Energies 2020, 13, 3359, doi:10.3390/en13133359. 
12. Ogbe, E.; Mukherjee, U.; Fowler, M.; Almansoori, A.; Elkamel, A. Integrated Design and Operation Optimization of Hydrogen Commingled with Natural Gas in Pipeline Networks. Ind. Eng. Chem. Res. 2020, 59, 1584-1595, doi:10.1021/acs.iecr.9b04550.

13. Guandalini, G.; Colbertaldo, P.; Campanari, S. Dynamic modeling of natural gas quality within transport pipelines in presence of hydrogen injections. Appl. Energy 2017, 185, 1712-1723, doi:10.1016/j.apenergy.2016.03.006.

14. Quarton, C.J.; Samsatli, S. Power-to-gas for injection into the gas grid: What can we learn from real-life projects, economic assessments and systems modelling? Renew. Sustain. Energy Rev. 2018, 98, 302-316, doi:10.1016/J.RSER.2018.09.007.

15. De Santoli, L.; Paiolo, R.; Lo Basso, G. An overview on safety issues related to hydrogen and methane blend applications in domestic and industrial use. In Proceedings of the Energy Procedia; 2017; Vol. 126, pp. 297-304.

16. Zhou, S.; Sun, K.; Wu, Z.; Gu, W.; Wu, G.; Li, Z.; Li, J. Optimized operation method of small and medium-sized integrated energy system for $\mathrm{P} 2 \mathrm{G}$ equipment under strong uncertainty. Energy 2020, 199, doi:10.1016/j.energy.2020.117269.

17. Park, C.; Kim, C.; Choi, Y.; Lee, J. Operating strategy for exhaust gas reduction and performance improvement in a heavy-duty hydrogen-natural gas blend engine. Energy 2013, 50, 262-269, doi:10.1016/j.energy.2012.10.048.

18. Correa, G.; Muñoz, P.; Falaguerra, T.; Rodriguez, C.R. Performance comparison of conventional, hybrid, hydrogen and electric urban buses using well to wheel analysis. Energy 2017, 141, 537-549, doi:10.1016/j.energy.2017.09.066.

19. Mehr, A.S.; Moharramian, A.; Hossainpour, S.; Pavlov, D.A. Effect of blending hydrogen to biogas fuel driven from anaerobic digestion of wastewater on the performance of a solid oxide fuel cell system. Energy 2020, 202, doi:10.1016/j.energy.2020.117668.

20. Wu, H.W.; Lin, K.W. Hydrogen-rich syngas production by reforming of ethanol blended with aqueous urea using a thermodynamic analysis. Energy 2019, 166, 541-551, doi:10.1016/j.energy.2018.10.122.

21. Deymi-Dashtebayaz, M.; Ebrahimi-Moghadam, A.; Pishbin, S.I.; Pourramezan, M. Investigating the effect of hydrogen injection on natural gas thermo-physical properties with various compositions. Energy 2019, 167, 235-245, doi:10.1016/j.energy.2018.10.186.

22. de Santoli, L.; Paiolo, R.; Lo Basso, G. Energy-environmental experimental campaign on a commercial CHP fueled with $\mathrm{H} 2 \mathrm{NG}$ blends and oxygen enriched air hailing from on-site electrolysis. Energy 2020, 195, 
doi:10.1016/j.energy.2019.116820.

23. di Gaeta, A.; Reale, F.; Chiariello, F.; Massoli, P. A dynamic model of a $100 \mathrm{~kW}$ micro gas turbine fuelled with natural gas and hydrogen blends and its application in a hybrid energy grid. Energy 2017, 129, 299-320, doi:10.1016/j.energy.2017.03.173.

24. de Santoli, L.; Lo Basso, G.; Barati, S.; D’Ambra, S.; Fasolilli, C. Seasonal energy and environmental characterization of a micro gas turbine fueled with $\mathrm{H} 2 \mathrm{NG}$ blends. Energy 2020, 193, doi:10.1016/j.energy.2019.116678.

25. Lo Basso, G.; Nastasi, B.; Astiaso Garcia, D.; Cumo, F. How to handle the Hydrogen enriched Natural Gas blends in combustion efficiency measurement procedure of conventional and condensing boilers. Energy 2017, 123, 615-636, doi:10.1016/j.energy.2017.02.042.

26. Demir, H.; Mobedi, M.; Ülkü, S. A review on adsorption heat pump: Problems and solutions. Renew. Sustain. Energy Rev. 2008, 12, 2381-2403, doi:10.1016/j.rser.2007.06.005.

27. Wu, W.; Wang, B.; Shi, W.; Li, X. An overview of ammonia-based absorption chillers and heat pumps. Renew. Sustain. Energy Rev. 2014, 31, 681-707, doi:10.1016/j.rser.2013.12.021.

28. Alahmer, A.; Ajib, S.; Wang, X. Comprehensive strategies for performance improvement of adsorption air conditioning systems: A review. Renew. Sustain. Energy Rev. 2019, 99, 138-158, doi:10.1016/j.rser.2018.10.004.

29. Pinheiro, J.M.; Salústio, S.; Rocha, J.; Valente, A.A.; Silva, C.M. Adsorption heat pumps for heating applications. Renew. Sustain. Energy Rev. 2020, 119, doi:10.1016/j.rser.2019.109528.

30. de Santoli, L.; Lo Basso, G.; Nastasi, B. The Potential of Hydrogen Enriched Natural Gas deriving from Power-to-Gas option in Building Energy Retrofitting. Energy Build. 2017, 149, 424-436, doi:10.1016/j.enbuild.2017.05.049.

31. Hamdy, M.; Askalany, A.A.; Harby, K.; Kora, N. An overview on adsorption cooling systems powered by waste heat from internal combustion engine. Renew. Sustain. Energy Rev. 2015, 51, 1223-1234, doi:10.1016/j.rser.2015.07.056.

32. Leonzio, G. Solar systems integrated with absorption heat pumps and thermal energy storages: state of art. Renew. Sustain. Energy Rev. 2017, 70, 492-505, doi:10.1016/j.rser.2016.11.117.

33. Jelmer Vellema Gas absorption heat pumps in the built environment; 2012; 
34. Chua, H.T.; Toh, H.K.; Ng, K.C. Thermodynamic modeling of an ammonia-water absorption chiller. In Proceedings of the International Journal of Refrigeration; 2002; Vol. 25, pp. 896-906.

35. Velázquez, N.; Best, R. Methodology for the energy analysis of an air cooled GAX absorption heat pump operated by natural gas and solar energy. Appl. Therm. Eng. 2002, 22, 1089-1103, doi:10.1016/S1359-4311(02)00028-5.

36. Engineering, M.C. Thermophysical Properties of NH3+H2O Solutions for the Industrial Designof Absorption Refrigeration Equipment. 2004.

37. Pátek, J.; Klomfar, J. Simple functions for fast calculations of selected thermodynamic properties of the ammonia-water system. Int. J. Refrig. 1995, 18, 228-234, doi:10.1016/0140-7007(95)00006-W. 